Memories of Odys Eus 
For Thomas 


\title{
Memories of Odysseus
}

Frontier tales from ancient Greece

\author{
François Hartog \\ Translated by Janet Lloyd
}

Edinburgh University Press 
(C) Éditions Gallimard, 1996

English translation (C) Janet Lloyd, 2001

Transferred to Digital Print 2011

This edition first published 2001 by

Edinburgh University Press Ltd

22 George Square

Edinburgh EH8 9LF

Scotland

French edition first published 1996 by Éditions Gallimard

5 , rue Sébastien Bottin

75007 Paris

France

English edition published with the aid of a translation subvention kindly given by the French Ministry of Culture

Typeset in 11 on 14 Ehrhardt

by Charon Tec Pvt. Ltd, Chennai, India

Printed and bound in Great Britain by

CPI Antony Rowe, Chippenham and Eastbourne

A CIP Record for this book is available from the British Library

ISBN 0748614486 (hardback)

ISBN 0748614478 (paperback)

The right of François Hartog

to be identified as author of this work

has been asserted in accordance with

the Copyright, Designs and Patents Act 1988. 